\title{
Basutoland and the Basuto
}

\section{Author(s): R. Crawshay}

Source: The Geographical Journal, Vol. 21, No. 6 (Jun., 1903), pp. 645-655

Published by: geographicalj

Stable URL: http://www.jstor.org/stable/1775656

Accessed: 27-06-2016 03:12 UTC

\section{Your use of the JSTOR archive indicates your acceptance of the Terms \& Conditions of Use, available at}

http://about.jstor.org/terms

JSTOR is a not-for-profit service that helps scholars, researchers, and students discover, use, and build upon a wide range of content in a trusted digital archive. We use information technology and tools to increase productivity and facilitate new forms of scholarship. For more information about JSTOR, please contact support@jstor.org.

The Royal Geographical Society (with the Institute of British Geographers), Wiley are collaborating with JSTOR to digitize, preserve and extend access to The Geographical Journal 


\section{BASUTOLAND AND THE BASUTO.*}

\section{By Captain R. CRAWSHAY.}

Wна'T is so commonly said of the people of Great Britain, that they do not know their own country, is more applicable to South Africa in general, and to Basutoland in particular, from without as well as within. If you question any ordinary ten people of the whites of our South African colonies as to what they take Basutoland to be, nine out of the ten will reply, "Why, part of Cape Colony." Question them further as to whether it is under the government of Cape Colony or not, and probably they will reply scornfully, "How otherwise?" It is no exaggeration to say that from without in South Africa the ignorance prevailing in regard to Basutoland is astounding, and that withinwith few exceptions - the whites do not know the correct native names or heights of mountains in sight and easy reach of which they have been living for years. As always in such countries, it is the missionaries who know most.

During ten months, in 1901-1902, I happened to be employed by Remounts in purchasing horses in South Basutoland. In this capacity, making Maseru my headquarters, I travelled over 2000 miles on horseback, by road and bridle-path, so had good opportunities of seeing something of the country and people from an outside point of view. By request, I now endeavour to record my impressions, which, given freely and frankly, "without partiality, favour, or affection," will, I hope, be taken in the spirit in which they are offered.

The Basutoland Protectorate-or Lesuto, as its people know ithas well been styled the Switzerland of South Africa. This is not as applicable to the western as to the eastern portion; nor is it at once remarkable on the 90-miles journey from Bloemfontein, the capital of the Orange River Colony, to the western border, because the change in the intervening country is gradual-from at first almost a dead open flat, relieved only by occasional low stony hills, to mountain and flat about equally proportioned. It is with Southern Basutoland that I have acquaintance, by which I mean from Maseru, the capital, to Kuthing, south of the Orange river, a distance of some 130 miles. This constitutes a country unique, probably, to all South Africa-densely populated, much cultivated, full of live stock; so much so, indeed, that there is not a foot of spare land. The monotony of the bare highland prairies of South Africa is not apparent in Basutoland, for here the face of nature changes at every turn. In all directions are mountains of striking contour-this one with a sugar-loaf peak-Machachi, that one with a flat saddle-back, from which rise potato-like excrescences-

* Strictly speaking, "Basotho," as a noun of Class 1. I observe the rule of the Society in retaining existing spelling, to avoid confusion.-R. C. 
Thaba Ntelle, another with a beakelike rostrum protruding at right angles into space-Kheme, the majority crowned with frowning precipices, but all with their upper slopes studded with boulders, and in most cases their summits of solid rock. There is a personality about each which makes one inquire its name.

Maseru is scattered over the slopes of several small hills within the bend of the Caledon river, here forming the western boundary of the Protectorate. Here reside the Resident Commissioner with his principal officials. The remaining white population consist of the clergyman, manager of the Standard liank, the proprietors and employés of four trading stores, a saddler, and the usual complement of carpenter-blacksmiths, who combine their third calling of lodging-house keepers as well. The native population is considerable and undesirable, owing to their disregard for sanitation.

For the purpose of administration, the country is divided into districts under assistant commissioners. The towns where these officials reside constitute, as it were, European reserves, where the white officials hold sway, whereas outside the chiefs are responsible for what goes on, subject to direction from the officials. The control exercised over the natives is of a dual nature-on the one hand European, on the other that of the chiefs, who retain practically supreme power over their people. It is not an infrequent occurrence for a man to be "eaten up" - that is, have all his property confiscated-by his chief, for perhaps a trivial offence. Power such as this is open to abuse; but were it taken from the chiefs, their medium would be unavailing to control their people. It may be fairly claimed for Basutoland that, if not strongly governed, it is yet governed-as it is believed-in the first interests of natives, by a resident commissioner, who, whatever may be the views held by the whites of South Africa as a whole, will not, if he knows it, see his people suffer injustice.

No one visiting the country for the first time, more especially if he be one who has seen much of other parts of South Africa, can fail to note what an object lesson it affords of the development of practical enterprise on the part of the African native.

Following the road sonth to the southernmost border, you pass through almost one continuous stretch of maize, wheat, oats, or sorghum, according to the time of year. No sooner is one crop out of the ground than another is put in. No manure is used, so cultivation goes on until the land exhausts itself, when there is nothing for it but to let it lie fallow to recover. It is surprising that, having attained so far, the Basuto have not attained further, in returning to the land the refuse of the crops in the shape of straw, instead of burning this on the clearings where the grain is threshed by the primitive method of beating it with sticks.

All cultivation--with rare exceptions-is done by the plough, drawn 
cither by oxen or ponies. Hoes are used for cleaning the crops, sickles for reaping. The men do the ploughing, harrowing, and sowing; men and women the hoeing and harvesting. Nothing could be more picturesque than the ordinary prospect in Basutoland, the rich green crops on the lowlands, the live stock grazing over the slopes, and the villages perched up amongst the crags, commanding a view of all below. In the spring or summer, when the air is clear, the contrast of colours in the green herbage, the brown houses, and the reddish-brown rocks resembles a peep into fairyland. At the same time, distance lends enchantment to the view, for the average Basuto are as filthy in their habitations and food as the wildest tribes of the interior-more so, indeed, in food than almost any people I have come across. An ordinary village consists of from less than half a dozen huts to, in the case of a chief, forty or fifty. The huts are of stone, thatched with grass. Many are rectangular, of good size, especially those of the chiefs, and in a few cases roofed with corrugated iron. The majority are circular, some 10 feet in diameter, with a fairly decent door, and perhaps one or more windows, ranging from mere holes blocked by a single stone or rag, to others 2 or 3 feet high by 2 feet broad. A reed fence forms a sort of courtyard to each hut, or perhaps several huts, the doorway hung with an old sack as often as not, and leading out on to the refuse mound, the accumulation perhaps of years. The precincts are impossibly filthybones, hoofs, horns, and other refuse lie about everywhere. In every village there are one or more "kraals" built of stone, in which at nights the live stock are kept.

In live stock and poultry the Basuto are distinctly well off; they have horses, asses, cattle, pigs, sheep, goats of several breeds, including the Angora, turkeys, geese, ducks, fowls, pigeons, and occasionally guinea-fowl. A few of the chiefs have ostriches-a standing grievanco to the people on whose crops they batten. On, or rather partially in, the ground are built little shelters of stone for the poultry, each large enough to accommodate a sitting bird. As all wild carnivora, and indeed all mammals larger than a mole, have been exterminated in the inhabited districts, the defenceless occupants are not molested. Dogs are the plague of the country-curs of every description, some showing a grotesque likeness to such noble ancestors as mastiffs, St. Bernard's, setters, and pointers; the majority of the ginger-coloured, prick-eared, sharp-nosed, curly-tailed type usually in favour with the African.

At one time, probably, the country was wooded with dwarf forest; now it is absolutely bare, except for scrub and heather high up in the mountains. The only fuel in use is the dung of cattle, the collecting and drying of which is a chief industry of the Basuto women all the year round. In the inhabited districts, there is no undergrowth larger than the wild raspberry and blackberry, both of which are widely distributed. There is no bracken-at least, I have seen none. A 
conspicuous flower in the low country is a dark-red wild zinya, in colonies here and there. Trefoils grow luxuriantly in most places, the commonest being one with a brilliant dark crimson flower, and leaves no larger than the shamrock. The British buttercup and red poppy are everywhere.

Nowhere in the world is there a country more destitute of game, furred or feathered. Follow the roads or bridle-paths, ride wide of these anywhere in the inhabited regions, and in 50 miles you will not see as much as a dropping of a hare or francolin. Everything in this way has been exterminated. Quail (C. capensis), being migratory, are to be had in their season in fair numbers, though mercilessly persecuted by men, boys, and dogs. A lovely blue rock pigeon (Phoonota vinacea) is fairly abundant, by reason of its haunts in the precipices being inaccessible. High up in the mountains Pelea capreolus (a small grey antelope) are fairly plentiful, though difficult of approach by reason of their goat-like haunts and habits, and their extraordinary powers of vision and hearing. Baboons inhabit such mountains as Machachi, though what they subsist on is a mystery. A fair bag of francolins and hares can be had on the higher mountains intervening between the native locations. In the low countries, on newly ploughed land, I have several times seen small flocks of ibis. A common and very confiding bird of prey seen everywhere, very often on the telegraph wires, is a small, beautifully coloured terracotta-red and French-grey kestrel. The hooded raven is as ubiquitous as in most African countries. Another species, all black and of lighter build, is especially amusing to watch, with his merry gurgling crow and dancing antics. During my stay in Maseru, I twice remarked a pair of large owls (Bubo verreauxi) in the eucalyptus and wattle plantation known as "Hades." Widow finches are very numerous, and destructive to crops. Larks and creeping warblers are the commonest birds in the open country. Bulbuls and sparrows are plentiful in the townships, where they levy heavy toll on the fruit. Rollers, hoopoes, and nightjars are very rarely seen. A few duck are to be seen now and again on out-of-the-way pools. It is not a snipe country. On the little-known slopes of the Drakensberg, on the eastern border, there are rumoured to be such mighty antelopes as the eland and hartebeeste, also leopards and other carnivora. Snakes are very rarely met with, if $I$ am to judge from my own experience. I collected one harmless species at 10,000 feet on Machachi, which Mr. Boulenger determines as Amplorhinus multimaculatus, one of the Psammophidæ, or sand-snakes; perhaps I saw the sloughs of about two more found in the lowlands. Two species of diptera-an Astrid and a pupiparous species-are parasitic on horses chiefly. Gastrophilus equi reproduces its species in the ordinary way, by depositing its ova on the hairs of the forehand, whence they are bitten off by the host, swallowed, and matured as larvæ in the stomach. Hippobosca rufipes has a more remarkable life-history, as given me by Mr. E. E. Austen, of the Natural 
History Museum: "The female produces a single living larva at a time, the lava attaining full growth within the body of the mother by means of a sort of placental connection with the wall of the oviduct. On being extruded, the larva at once pupates, in consequence of which the group of flies to which Hippobosca belongs has been termed Pupipara." There is much to be done for entomology in the highlands, and even in the lowlands, in the less-known orders. In fact, I think up to the time of my visit nothing in this way had been collected, except Rhopalocera by Mr. Trimen long ago. Quite a number of my Heterocera proved new; also one Rhopaloceron, taken high up in the mountains, a good many Hymenoptera, and one large Arachnid, described by Mr. IR. I. Pocock. The only land-shell so far recorded from Basutoland is one from Machachi, described by Mr. Edgar Smith as Achatina Machachensis, n. sp.

The Basuto deserve every credit for their energy and industry in agricultural derelopment, even though the motive be money wherewith to purchase live stock and wives. But when this has been said for them, with the exception of such enlightened chiefs as Jonathan Molapo and those of the younger generation who have been highly educated by the missionaries, they are far below the natives of the interior in that healthy morale which characterizes wild men.

All who have travelled in the interior of Africa will have experienced the extraordinary hospitality of its peoples, though it may be not all at once, perhaps, because either the strangers are objects of terror or suspicion, or because they will precipitate hostilities by helping themselves to what they find without first exchanging-what very often are the most absurd-preliminary courtesies, or for some other reason. Invariably, when once friendly relations have been established, hospitality is met with everywhere; whatever the people have in the shape of food they bring -fowls, eggs, vegetables, grain ; in the case of chiefs, a goat, a sheep, or a bullock. If such hospitality is withheld, it is considered hostility - in fact, a declaration of war, if not explained. During my time in Basutoland, it often happened that I slept out where night overtook me, sometimes without a bite of food or drink, but never once did a native offer me anything, nor would they sell me as much as an egg at any price. On the other hand, from their chiefs downwards, they were not ashamed to beg. Nsani of Maseru came to me to beg meat from the carcase of a Government horse on which I was holding a post-mortem.

A fair test of the African's status as a man is the standard of virtue prevailing amongst his female kind. It used to be said of the Amazulu, "A waggon-load of trade goods will not buy the dishonour of a woman!" The same applied to the Nyasa tribes in days gone by. Doubtless it still holds good, except in the case of abandoned women in the neighbourhood of European settlements. It cannot be said of 
the Basuto women, whose immorality is without restraint. What a contrast to the women of the interior, whose modesty is such that, even when in a European's employ for quite a time, they will rarely address a word to him on any matter however urgent, nor can they readily be brought to reply to a question addressed to them in connection with their work or pay! The result of this polyandrous propensity on the part of the Basuto women is that disease is exceedingly prevalent.

The Basuto possess almost none of that interest which attaches to wild men. Their natural habits, the outcome of instinct, have been lost from contact with whites, whose vices they have absorbed, without their virtues. The first impression one has of them is that they are a mongrel race, not Bantu, but a cross between these and some xanthous people of South Africa, with perhaps some European blood as well. All colours are they-bronze, yellow, and yellowish-white. A common feature noticeable amongst them is a long hooked nose, of Semitic shape above, having the squat tip and wide-open orifices of the negro. Some have hatchet faces, beetle brows, lantern jaws, thin lips, or almost almond-shaped eyes. Bishop Steere's definition of a "nigger" as opposed to a "native" used to be "a native in European clothing." Dress up a negro with a view to making him as grotesque a figure as possible, and you have a very fair idea of the ordinary Mosuto. A tawdry multi-coloured woollen night-cap with a bobbin-like tassel is worn, pulled down over the head, covering the brow, the ears-as often as not-and the nape of the $n \in c k$. 'The only upper garment of any sort is a coloured woollen blanket or shawl with fringes, worn humped over the shoulders, where it is pinned by a safety-pin about 6 inches long, specially imported for the purpose. Below this are trousers, tattered and plastered with patches of cloth of all kinds, retained in position by a money-belt, or it may be braces. Clumsy boots, with or without putties, or bandages of rags, complete the illusion. Figures such as these throng the towns and elbow and jostle one another in the stores, or are to be met on the roads and paths, perched on the backs of unkempt ponies. No Mosuto will walk a yard if he can help it; failing: a pony or donkey, they will ride an ox or a cow, small boys at play even a goat.

The dress of the women resembles rather that of the Dutch. On their heads they wear coloured handkerchiofs tied under the chin, bright colours, such as orange, yellow, and green, being in especial demand. The only other garment is a plain print dress, with a shawl over the shoulders. Women living in the towns as a rule wear stockings and shoes.

The above description applies only to the Basuto as a whole. In the case of some chiefs and of the educated members of the tribe, their dress is identical with that of the European in the minutest detail, even to high linen collars. 
European settlements are a pleasing contrast to other parts of the country, for they are green oases in an otherwise treeless waste. Many European timber trees and all fruit trees thrive well with little care. The oak grows as luxuriantly and twice as fast as in Great Britain, bearing acorns more than double the normal size. Its timber is not as hard, owing to its quicker growth. Scotch firs-indeed, all firs-do particularly well; also the walnut, Spanish chestnut, beech, mountain ash, and black poplar. The willow does well in moist land. I was disappointed not to see either the elm or the lime. In the residency garden at Maseru there are many familiar shrubs from home, including lilac, laurel, box, and syringa. Common creepers on the houses of Europeans are jasmine (white and yellow), honeysuckle, clematis, and passion flower. Privet as a fence grows with great vigour, a mass of strong-smelling flower in the summer. The quince also is largely utilized for fences, so that, with its handsome and highly edible bright yellow fruit, it is as profitable as conspicuously pretty. Fences of cherry are occasionally seen; one in particular do I remember in the Government secretary's garden, which provided more than one cherry tart for the police mess. Owing to the complete rest afforded by the hard winter, stone fruits grow anyhow, bearing crops so heavy as to cause their branches to split under the weight. There are apricots, peaches, nectarines, a few plums, greengages, pears, apples, mulberries, figs, and grapes, not always, it may be, producing fruit of the best quality, but in astounding quantity. Never anywhere have I seen heavier crops of apricots than on some of the trees in the police mess garden at Maseru. Bush fruits I saw none, except two stunted gooseberry bushes in the garden at Motsekuwa. The strawberry is widely distributed. The winters are too severe for such tropical fruits as the banana, the pawpaw, and the custard apple. Lemons do very well at Moriya; oranges are nowhere a success. Vegetables are somewhat disappointing-perhaps because they do not receive sufficient care. Cauliflowers, cabbages, Jerusalem artichokes, beans, and asparagus are about the best. Potatoes, as a rule, are very poor.

The great mistake made hitherlo in timber-planting in Basutoland has been the universal introduction of the eucalyptus, with its known tendency to desiccate - in a country already too dry - and to poison all other vegetable growth in its vicinity. The Australian wattle would have been preferable.

Firs would have been best of all, for, though slow growers, they thrive capitally, and, shedding their spines, these retain the moisture in the soil after the manner of coconut-fibre.

Much has been written of the pony of the country-that he is a paragon of soundness, of bottomless endurance, worth any money. After ten months' purchasing for army requirements, my experience is, the first qualification is rarely met with in adult animals; the second 
results from the spartan rearing, involving the survival of only the fittest; and, granted the two first, the third follows as a matter of course. The Mosuto-after the manner of the native-is a bad master to his beast, using him hardly, working him as if regardless of his being flesh and blood, and begrudging him any other food than such grass as he is able to pick up for himself. No compassion is shown for either extreme youth or old age.

By far the most interesting portion of the Protectorate is the mountainous eastern half, commencing about 30 miles east of Maseru, and extending to the Natal border. Unfortunately, having my duty to do, the most I was able to do was to enter the promised land-in other words, to make the ascent of Mount Machachi and put in three days on its slopes. This had been reported to me to be the highest mountain in the country, 11,000 feet; but I was afterwards assured by the Rev. R. H. Dyke, of Moriya, whose father was the pioneer Huguenot missionary in, I think, 1844, that Mount Hamilton, on the eastern border, is considerably higher-over 12,000 feet, and that Machachi is not as much as is believed by the Protectorate officials.

Leaving my spare horses and mules at a point about 7 miles from the foot of the mountain, and using two ponies for our packs, myself and servant, with two natives, walked to the base, and the next morning climbed the mountain by a fairly good, though steep, circuitous track to a col some 800 or 1000 feet from the summit, where we put in two nights in the open. It was in the rainy season, but, with the exception of the first night, the weather was fine, though cold and boisterous.

From the bare ill-watered lowlands to the slopes of Machachi, with its abundant clear cold streams, its invigorating atmosphere, its profusion of wild flowers, and new forms of insect and animal life at every turn, was indeed a delightful change. About half its time the rocky peak is nidden in the clouds. During the cold season the snow lies for weeks and months on the upper slopes.

Pelea capreolus are tolerably plentiful at the higher altitudes, and I was glad to bave this opportunity of observing them. Like goats, they look for danger from below, not from above. From the nature of the country they frequent they are difficult to approach, for the slopes are open, steep, and covered with loose stone, and, sound travelling readily, the least noise made by displacing a stone tells its tale. Then from the slope above or across a valley comes the weird cry of alarm"Haa!"-from a buck standing motionless amongst rocks the colour of his coat. I have tried to locate the whereabouts of a buck for several minutes, during which he has periodically uttered his alarm, but have not been able to distinguish him until, in turning to go, his white tail betrays his form. High up on the mountain I remarked a field rat with large ears, of which I could not secure a specimen, having neither a gun nor a trap. 
Wild flowers are in extraordinary profusion-heaths, ixia, gladioli, byacinths, primulæ, carnations of tiny size, meadow orchids, grania, and ferns.

The summit of Machachi is of solid rock, in process of disintegration in the alternating heat and frost. Dr. Flett, of the Geological Survey Museum, has determined a specimen of this to be amygdaloidal lava, eontaining apophyllite and prehnite, coated with dark green chlorite. Another rock from 1000 feet lower altitude is pronounced by the same authority to be ophitic olivine dolerite reddened by decomposition.

All over the mountain there are abundant streams of the clearest water possible, often flowing over beds or through basins of solid rock. Water oozes from under the rocks within 150 feet of the summit.

Parts of the mountain are sheer precipice, especially to the northwest and north-east. From the summit, looking exstward, the view is one of magnificent and weird grandeur, a knotted mass of mountains, little inferior to Machachi, the contour of which no man's eye could define. In the opposite direction, the vast expanse of what in comparison is flat country lacks salient features on this account, and, at the time I viewed it, was much obscured by the lowland haze.

Much has been written in reports of the richness of Basutoland as a grain country, producing for its size more maize and wheat than any other part of South Africa. If this is to be maintained in the future, some effective scheme must be evolved to preserve the rainfall for the land, and prevent the wholesale wash off and wash out of the Earth's surface ever increasingly going on. In the neighbourhood of towns, on the roads and tracks, and on slopes denuded of vegetation, watercourses are formed-at first the merest crevasses, ultimately becoming huge ravines 30 or 40 feet wide and 20 deep, which receive the rainfall of a large area of land, bearing this away with little or no benefit to the land drained, at the same time washing off its top soil in doing so, besides carrying away huge masses of earth from the banks of the ravines themselves. What is wanted is to arrest the growth of such watercourses where formed, and to prevent their formation by enabling the land to absorb its rain, which may be done by not denuding it of its grass-better still, by planting timber. It is, of course, hopeless to look to native enterprise to do anything in this way. Therefore it can only be done by Government, with funds raised by taxation.

Bridges are badly wanted across the Great Caledon river (where, when the river is very high, the pont cannot work), the Little ('aledon river, and the Makhaleng river on the north of Mohaleshoek, which, in the rainy season, delay traffic for days on end, causing loss of property and sometimes loss of life as well.

It is late somewhat to legislate for contagious diseases, but much good might yet result from this, in the case of man and beas ${ }^{2}$. No country in all Africa could be better off in facilities offered to the

No. VI.-JUNE, 1903.] $2 \times$ 
natives to educate themselves. There are mission stations at every few miles-those of the Church of England with its headquarters at Masite, the Roman Church, and, most numerous of all, the French Protestant Mission with its headquarters at Moriya. All are deserving of the greatest credit for the pitch of education to which so many of the joung Basuto have attained.

No man could desire a healthier or pleasanter climate than that of Basutoland. It nearly resembles what that master man and mind, Sir Richard Burton, has termed the "champagne air of the desert." Never does one experience any sensation of lassitude. It is hot in the hot season, though not oppressively so. During the summer I was there, the maximum temperature in the low country, i.e. 5000 to 5500 feet, did not, I think, exceed $94^{\circ}$. The cold is proportionately much greater, $15^{\circ}$ to $20^{\circ}$ of frost not being uncommon, accompanied by hail, snow, and cutting winds, fatal alike to man and beast. In June, 1902, there was just such a spell of cruel weather-hail, snow, rain, wind, and frost, in conjunction or rapid succession, productive of wholesale disaster. There were reported to have died from exposure to it, between Aliwal north and the south-west border of Basutoland, some twenty-eight natives. There was hardly an owner of live stock in the country who did not suffer heavily. For quite a fortnight the snow lay at Mafeteng, altitude about 5100 feet. As is only to be expected: from the conformity of the country, there are terrific thunderstorms in the hot season. If the traveller comes in for one in the Moriya-MasiteKheme valley, he cannot fail to be impressed by the awful grandeur. of the elements - the inky black masses of clouds rushing together from over the mountain-tops, the lurid lightning thrilling him to his marrow, the deafening thunder exploding and, as it were, splitting the rocks on the slopes above, the rain and wind which he and his horse cannot face. For the time being, he realizes what it is to feel at the mercy of the Creator. Luckily, such storms are of short duration; thirty minutes and the worst is over. The difficulty then is the impassability of the streams and watercourses, to say nothing of the slippery state of the paths.

\section{The Sesuto Language.}

On first hearing Sesuto spoken, it appears not to be a Bantu tongue. On closer acquaintance, there can be no doubt it is, though of another class to that of the tribes of equatorial Africa. It abounds in the letters $h$ and $o$. Many words end in $-n g$.

Seven classes of nouns only are admitted in what is at present the standard grammar, compiled by Mabille and Jacottet. Myself, I should be inclined to revise these by altering the prefix of one, and by adding three more classes :-

Cuass I.-Prefix : sing. " mo-," pl. " ba-" : motho, batho, = person.

Cuass II.-Prefix : sing. " mo-," pl. " me-" : motsi, metsi, = village.

CiaAsS III.-Prefix : sing. "le-," pl. " ma-" : leiba, maiba, = blue rock pigeon. 
Class IV.-Prefix : sing. " se-," pl. "li-": seolo, liolo, = ant-hill.

Classs V.-Prefix : sing. "bo-," pl. " ma-": bosiu, masiu, = night.

Class VI.-Having no prefix in the singular: ntsintsi, dintsintsi, $=\mathrm{fly}$.

Class VII.-Having irregular plural: leihlo, mahlo, =eye; leino, meno, = tooth.

Class VIII.-Having no prefix : metsi, = water.

CLAss IX.-Infinitives of verbs: "ho": ho palama, = to ride, riding.

Class X.-Locative : " ha."

I am indebted to Sir Harry Johnston for the insertion of Class X.

A few common verbs are-

$$
\begin{aligned}
\text { Ho ya } & =\text { to eat. } \\
" \text { nwa } & =\text {, drink. } \\
" \text { tlisa } & =" \text { bring. } \\
\text { tlosa } & =" \text { take away. }
\end{aligned}
$$

Ho bela $=$ to cut grass.

"thiba $=$, stop.

" bitsa $=$, , call.

$"$ lema $=$ " cultivate.

At a person's is expressed by "ha." "Ha Bereng" = "At Bereng's." At, on, or in a place, by a suffix ending in -ng: "Thabaneng" = "On the hill." The usual greeting is "Dumela!" or if addressed to a chief or European, "Dumela Morena!" "I trust you, chief!" to which the reply is a long-drawn " $\mathrm{E}-\mathrm{E}-\mathrm{E}$ !" This, as a rule, is followed by the question, "U ea kae?" = "Where are you going?"

As a people, the Basuto are impertinently inquisitive, questioning one or one's followers on meeting, continuing this until they have passed out of earshot, or even accompanying one some distance to do so. Many hundreds of times have I been obliged to rid myself of noisy inquirers by telling them to go their way and leave me to go mine. A common practice is to ask for matches-even to stop one expressly for the purpose, by shouting from a distance.

From this, and from their general behaviour to Europeans in a hundred other ways, it is obvious they have not that respect for them which, from contact with the tribes of the interior, and even the Zulus, one has come to expect. Familiarity with the lowest class of white, some of whom are to be found in Basutoland, has bred contempt.

\section{THE ANTARCTIC EXPEDITION.}

THE mails which reached this country during the month of May have brought numerous private letters from members of the British Antarctic Expedition as well as the official report of Captain Scott. The latter will form the basis of the communication to be made by the President at the meeting of June 10, on the results of the first season's work in the Antarctic; but various details, supplementing those previously published, are to be gathered from the letters above alluded to, extracts from which have been published in the public press. The fuller information thus available confirms in the most satisfactory manner the favourable impression conveyed by the original telegram as to the results attained, both at the base station and during the various sledge expeditions. Among the most important geographical results, 